\title{
Non-Invasive Hemodynamic Analyses to Guide Pharmacotherapy of High Blood Pressure: Mini- Review
}

\author{
Chacon-Lozsán F* \\ Venezuela Central University, Venezuela
}

Submission: February 02, 2017; Published: March 02, 2017

*Corresponding author: Chacon-Lozsán F, University City, Venezuela Central University, Caracas Universitiy Hospital, European Council on Hypertension, European Society of Cardiology, Caracas, Venezuela, Email: Franciscojlk@hotmail.com

\begin{abstract}
Hypertension is the biggest risk factor to cardiovascular events, stroke and kidney disease, despite a numerous antihypertensive drugs, control rates still suboptimal. In the present mini-review, we will analyze an emergent method to control high blood pressure using hemodynamic parameters. We found seven trials since 1996 to 2106, a total of 1087 patients were studied comparing the standard method with the hemodynamic method with a success rate mean of $72,6 \%$ in control blood pressure values using hemodynamic method. Hemodynamic guided pharmacotherapy has demonstrated be superior to standard recommendations con control high blood pressure, the assessment of more hemodynamic variables aloud to the physician to analyses more detailed the accurate parameter to guide antihypertensive therapy, however, more controlled trials are needed to increase evidence of this emergent method.
\end{abstract}

Keywords: Hypertension; Resistant hypertension; Hemodynamics; High blood pressure; Goal therapy; Hemodynamic individualized therapy

\section{Introduction}

Hypertension is the most common chronic health disease and is well related to high risk factor for cardiovascular events, strokes and kidney disease. European hypertension guidelines, defines hypertension when values are equal or superior to $140 \mathrm{mmHg}$ to systolic blood pressure and or $90 \mathrm{mmHg}$ to diastolic blood pressure based on epidemiological studies that suggest that treatment-induced blood pressure reduction in this patients are beneficial [1]. A more extended definition of hypertension may be a complex syndrome than alters vascular resistance affecting all circulatory systems, related to many pathophysiological factors like oxidative stress, increased sympathetic nervous system activity, altered sodium-retaining hormones, dysregulation in renin-angiotensin-aldosterone system [2].

Blood pressure is the product of cardiac output and total peripheral vascular resistance, so any change in this elements will have a direct effect on blood pressure, in the other hand, cardiac output depends on three important factors, stroke volume, heart rate, and preload [3]. Because all the possibilities that can create is disease in this system to rise blood pressure and product organ damage, we need to identify which parameter is failing to guide therapy more accurate and control blood pressure.
In the present article we will review all literature about use of hemodynamic measurements to adjust antihypertensive therapy to control blood pressure and its outcome in control blood pressure compared with standard protocols. We use Medline and PubMed database to search all articles, and keywords used to search were "hypertension", "resistant hypertension", "hemodynamics", "therapy individualization" and "goal-directed therapy".

\section{Discussion}

Seven trials were founded between 1996 and 2016, randomized trials only 3 , the oldest trial form Sramek B et al. [4], a non-randomized trial in 1996, enrolled 322 patients previously treated by conventional therapy, non-controlled using at least 2 antihypertensive drugs, they observed a $75 \%$ became "normodynamic" or controlled after 3 weeks follow up. Next study was the Teler's et al. [5] study, in 2002, in this study, the first randomized trial in 104 patients with resistant hypertension divided in 2 groups, one treated with conventional therapy with certified hypertension specialist and the other one, treated with hemodynamic goal-directed therapy in 3 months follow up, in this study they reached a 56\% control of blood pressure in hemodynamic arm and $33 \%$ of control in conventional therapy arm with a statistical significant result $\mathrm{P}<0,05$. 


\section{Journal of Cardiology \& Cardiovascular Therapy}

In 2004, Mehra M et al. [6] published a series of 56 clinical cases previously non-controlled patients enrolled in a nonrandomized trial and applied the hemodynamic goal-therapy protocol to archive blood pressure control, they fund a 57,1\% $(\mathrm{P}<0,001)$ of success. The fifth study in the list was the Smith's et al. [7] trial in 2006, a randomized study with 164 enrolled Table 1: Hemodynamic algorithm to control blood pressure.

\begin{tabular}{|c|c|c|c|}
\hline Treatment Options & Cardiac Index & $\begin{array}{c}\text { Systemic Vascular } \\
\text { Resistance Index }\end{array}$ & Thoracic Fluid Content \\
\hline $\begin{array}{c}\text { Angiotensin converting } \\
\text { enzyme I, Angiotensin II } \\
\text { receptor blocker, calcium } \\
\text { channel blocker or direct } \\
\text { vasodilator }\end{array}$ & Normal or low & High & - \\
\hline $\begin{array}{c}\text { B-blocker or non- } \\
\text { dihydropyridine calcium } \\
\text { channel blocker }\end{array}$ & High & Normal or low & - \\
\hline Diuretic & Normal or high & Normal or high & High \\
\hline
\end{tabular}

The second trial, published in 2008 by Sremek et al. [8] studied 56 patients with uncontrolled hypertension and applied the hemodynamic method classifying patients in 4 groups based on intravascular volume, inotropy and vasoactiviy (Table 1) and adjusted medications according the result with a success in control blood pressure of $84 \%$ and 87,5 \& of no side effects reported. Another non-randomized trial was performed by Table 2: Trials using hemodynamic assessment of high blood pressure.

\begin{tabular}{|c|c|c|c|c|}
\hline Trial & Year & $\mathrm{n}$ & Intervention & Outcome \\
\hline Sramek et al. [4] & 1996 & 322 & $\begin{array}{c}\text { Prospective } \\
\text { nonrandomized trial }\end{array}$ & $\begin{array}{l}75 \% \text { of patients with blood } \\
\text { pressure controlled }\end{array}$ \\
\hline Taler et al. [5] & 2002 & 104 & $\begin{array}{l}\text { 1:1 randomized, } 3 \text { months } \\
\text { prospective, specialist vs } \\
\text { hemodynamic protocol in } \\
\text { refractory hypertension } \\
\text { subjects }\end{array}$ & $\begin{array}{l}56 \% \text { of patients with } \\
\text { resistant hypertension } \\
\text { with blood pressure } \\
\text { controlled }\end{array}$ \\
\hline Mehra et al. [6] & 2004 & 56 & $\begin{array}{l}\text { Prospective trial with non- } \\
\text { controlled patients using } \\
2 \text { antihypertensive agents } \\
\text { and apply hemodynamic } \\
\text { protocol to control blood } \\
\text { pressure. }\end{array}$ & $\begin{array}{l}57,1 \% \text { of patients with } \\
\text { blood pressure controlled }\end{array}$ \\
\hline Smith et al. [7] & 2006 & 164 & $\begin{array}{c}\text { 3:2 randomized } \\
\text { prospective, } 3 \text { months } \\
\text { follow standard vs } \\
\text { hemodynamic protocol }\end{array}$ & $\begin{array}{l}77 \% \text { of patients with blood } \\
\text { pressure controlled }\end{array}$ \\
\hline Sramek et al. [4] & 2008 & 56 & $\begin{array}{l}\text { Prospective non- } \\
\text { randomized trials with } 3 \\
\text { months follow up }\end{array}$ & $\begin{array}{l}84 \% \text { of patients with blood } \\
\text { pressure controlled }\end{array}$ \\
\hline Aoka [9] & 2009 & 113 & $\begin{array}{l}\text { prospective non- } \\
\text { randomized trial, } 4 \text {, } \\
7 \text { months duration }\end{array}$ & $\begin{array}{l}72 \% \text { patients with blood } \\
\text { pressure controlled }\end{array}$ \\
\hline Krzesinski & 2016 & 272 & $\begin{array}{c}\text { 1:1 Randomization, } \\
12 \text { weeks prospective, } \\
\text { conventional Vs } \\
\text { Hemodynamic protocol } \\
\text { with previous captopril } \\
\text { washout in hypertensive } \\
\text { patients. }\end{array}$ & $\begin{array}{l}87,7 \% \text { of patients with } \\
\text { blood pressure controlled }\end{array}$ \\
\hline
\end{tabular}

patients, non-controlled with standard therapy and before start study, patients had a 2 weeks washout of antihypertensive medication and there were no differences between groups in blood pressure parameters before start protocols, they found a $77 \%$ of blood pressure control in the hemodynamic arm, compared with a $57 \%$ of control in standard therapy $(\mathrm{P}<0,01)$.
Aoka et al. [9] in 2009, enrolling 113 uncontrolled patients with hypertension and a follow up of 4,7 months with a $72 \%$ of success using hemodynamic goal-directed therapy. The last trial in medical database consulted was the Krazesinsky's trial from 2016, a randomized trial with 272 enrolled patients, they had a $87,7 \%$ of control of blood pressure compared with the $69,1 \%$ of

the standard therapy $(\mathrm{P}=0,012)$. 
After all search, seven trials in 20 years, 1087 patients with a success rate mean of $72,6 \%$ in control blood pressure values (Table 2). Hemodynamic approaches of blood pressure have its rationale in all different hemodynamic mechanism of hypertension, this mechanisms were described by Tarazi [10] in 1983, according to him, hypertension can be explained by alterations in vascular resistance, cardiac output or intravascular volume; in agreement of this, antihypertensive agents are classified in order of its mechanism of actions, for example, diuretics reduces intravascular volume, angiotensin converting enzyme inhibitors have his primary effect on vascular tone, and B-blockers on cardiac output. According to this hypothesis, the hemodynamic assessment of high blood pressure can be a more pathophysiological accurate method to guide antihypertensive therapy.

\section{Conclusion}

Hemodynamic guided pharmacotherapy has demonstrated be superior to standard recommendations con control high blood pressure, the assessment of more hemodynamic variables aloud to the physician to analyses more detailed the accurate parameter to guide antihypertensive therapy, however, more controlled trials are needed to increase evidence of this emergent method and outcomes like mortality, side effects and reduction in organ damage.

\section{References}

1. Mancia G, Fagard R, Narkiewicz K, Redon J, Zanchetti A, et al. (2013) $2013 \mathrm{ESH} / \mathrm{ESC}$ Guidelines for the management of arterial hypertension:
The Task Force for the management of arterial hypertension of the European Society of Hypertension (ESH) and of the European Society of Cardiology (ESC). European Heart Journal 34(28): 2159-2219.

2. Oparil S, Zaman MA, Calhoun DA (2003) Pathogenesis of hypertension. Ann Intern Med 139(9): 761-776

3. Egan B, Schmouder R (1988) The importance of hemodynamic considerations in essential hypertension. Am Heart J 116(2 Pt 2): 594599.

4. Sramek B, Tichy J, Hojerova M, Cervenka V (1996) Normohemodynamic goal-orientes antihypertensive therapy improves the outcome. Am J Hypertens 9: 141A.

5. Taler S, Textor S, Augustine J (2002) Resistant hypertension: comparing hemodynamic management to specialist care. Hypertension 39(5): 982-988.

6. Sharman DL, Gomes CP, Rutherford JP (2004) Improvement in blood pressure control with impedance cardiography-guided pharmacologic decision making. Congest Heart Fail 10(1): 54-58.

7. Smith R, Levy P, Ferrario C (2006) Value of noninvasive hemodynamics to archive blood pressure control in hypertensive subjects. Hypertension 47(4): 771-777.

8. Sramek B, Badlia E, Bartos D, Tirziu D, Ghiorge S (2008) Treating hypertension as a hemodynamic disorder results in three-fold improvement in outcomes. J Clin Hypertens 10 (Suppl A): A81.

9. Aoka Y (2009) Limitations of monotherapy and benefit of impedance cardiography as a guide for a combination therapy in archiving blood pressure control in essential hypertension. J Clinhypertens 11: A21.

10. Tarazi R (1983) The hemodynamics of hypertension. Hypertension: physiopathology and treatment. ( $\left.{ }^{\text {nd }} e d n\right)$, McGraw-Hill Book company, New York, USA, p. 14-42.

\section{Your next submission with Juniper Publishers} will reach you the below assets

- Quality Editorial service

- Swift Peer Review

- Reprints availability

- E-prints Service

- Manuscript Podcast for convenient understanding

- Global attainment for your research

- Manuscript accessibility in different formats

( Pdf, E-pub, Full Text, Audio)

- Unceasing customer service

Track the below URL for one-step submission https://juniperpublishers.com/online-submission.php 